\title{
SCIENCE, RELIGION, AND THE SCOPES CASE
}

\author{
MALCOLM P. SHARP*
}

S IMPLIFYNG the history somewhat, we may say that a Tennessee statute prohibiting the teaching of organic evolution in public educational institutions was held applicable to a public-school teacher of biology. Mr. Kalven has given us refinements about the statute and the case, but this is a tenable and simple statement of the result. The Tennessee statute is still law in Tennessee, though no one seems to know what effect, if any, it is having today.

Is such a statute constitutional? In particular, is it in conflict with a state or federal constitutional provision in the form of the first amendment, prohibiting legislation abridging freedom of speech? There is apparently no decided case which throws any significant light on the problem. Some help may, as usual, be derived from general discussions in Supreme Court opinions, for example, the opinion in the foreign language teachers' case. But the statute raises unanswered questions. If the discussion is speculative, it may nevertheless have a certain interest.

The inevitable operation of selection in the curricula of public schools and universities is entrusted to faculties, boards and in the end to legislators. Though the study by astrologers of critical days in illness is said to have given us the training which produced Galileo, it is doubtful whether anyone would seriously advance the claims of astrology to inclusion in a modern curriculum. Even in the late 1930's few, if any, reputable English or American anthropologists would have proposed that time be devoted to a serious consideration of Hitler's racial theories, except perhaps as a taking-off place for the discussion of better-supported views. Last year the University of Chicago withdrew support from a board of the Chicago Review, a literary publication interested in printing rather severe and depressing, but outspoken and sometimes "obscene," poetry and stories. It is hard to raise a serious question about the University's obligation to support any particular administration of a publication of this sort, though the somewhat censorious tone of the action taken seemed an example of the improper use of scowling as sanction.

In cases suggested by these three examples, no expert has anything like a "right" to get or retain employment or to promotion; and a teacher's only legitimate protection is in cases of contractual tenure. While difficulties may be raised about contractual tenure, anyone who has seen an administration carried away by enthusiasm will appreciate its advantages. In the cases suggested by the examples given, only impartial and expert outside testimony

* Professor of Law, The University of Chicago Law School. 
to the effect, for example, that a teacher is losing his mind, should lead to any qualification of the guarantees of tenure. Hereafter, everything that is to be said should be taken subject to a qualification about tenure.

More difficult questions about the use of the sanctions of non-hiring, nonpromotion, the discharge of teachers without tenure, and scowling are raised by other problems. Since at least as early as 1948, I have consistently advocated that a good university, private or state-supported, should make a positive effort to have a qualified Marxist-Leninist-Stalinist, or now a Marxist-Leninist, on its humanities or one of its social science staffs. I am prepared to recommend individuals, and for the sake of the argument let us pass the point that there is no such person who is qualified to teach. Correspondingly I consider that non-hiring, non-promotion, discharge, and scowling are inappropriate sanctions to apply to Communists teaching human subjects in a university. Is there, however, any limit to the application of these sanctions in the text of such a constitutional provision as that to which we have referred in speaking about the teaching of evolution? This is an embarrassing question for me, as I am prepared to suggest that the teaching of evolution, in parallels to the various cases supposed, has constitutional protection. Let us leave the Communist illustration, for the moment at least, and recall various questions which the reader may consider related to it, in reflecting on some problems about the employment and treatment of individual teachers.

A teacher may be in practical diffculty today as in other days for expressing in the classroom untraditional views about one or all of the great conservative institutions: the church, the family, property, and the state. May the views on these matters seriously held by a competent teacher in the human subjects legitimately affect his treatment by a university?

Let me suggest quickly some brief answers. It would be shocking to hold a teacher disqualified on account of atheism from teaching in any of these fields; but a contemptuous attitude toward the religious beliefs of others might indicate a feeling which would lead us to reconsider a judgment of competence. If an atheist can be found who is qualified and willing to teach in a school of theology, his appointment, however unconventional, would be a useful one. It would be shocking to hold a student of Kinsey disqualified from teaching in a department of biology or sociology. Similarly, a professor who thinks that the ciminal law should not provide punishments for any consensual sexual relations among adults is not thereby disqualified; indeed this seems to be the opinion of a considerable number of the most conventional students of the subject. On the other hand, a teacher who taught, as a University of Chicago teacher was falsely accused of doing in the 1930's, that no attention should be paid to any of the restrictions connected with any form of family, would raise serious doubts about his competence. Whatever their other views about the family, psychiatrists of standing would agree, I think, that teaching of this sort is like astrology or Nazi race theory. 
We are considering here problems of teaching and control. The controversial discussions in question are incidental to teaching in the classroom. In informal discussion with students, oral or printed, as in public discussion generally, a teacher's freedom to speak without interference by any of the means available to an administration should be unlimited, where he speaks on public issues, up to the point where discussion turns into direction or command. The case of Professor Leo Koch at Illinois is an example of what seems an improper use of administrative sanctions. This paper is primarily concerned with a different subject, but nothing said here should be taken to indicate any doubt that Professor Koch's public expression of views about the family should be immune to academic discipline. If his classroom discussion of botany should somehow lead to classroom discussion of the human family, a problem about his qualifications might perhaps be presented to his university. As the case stands, he was expressing serious views about an important institution under circumstances where administrative control seems inappropriate.

The family and property are related institutions. It is the Marxist position that capitalist forms of property depend on misappropriation; the capitalist theory, that the Marxist revolution depends on misappropriation. I have suggested that this circumstance should not be a reason here for refusing to employ or promote a Communist teacher in one of the human subjects. It must be apparent that a comparable observation could be made about any refusal on the part of the University of Moscow to employ a teacher disposed to support capitalist views of property. At the same time, it would be hard to defend a teacher in Chicago, Cambridge, or Moscow who advocated in the classroom casual purse-snatching or the misuse of others' funds as a harmless sport or a relief from psychological tension.

The philosophical anarchist is critical of all the conservative institutions we have discussed and of the institution of government as well. That quizzical anti-Fascist, Pareto, whose understanding of Fascism misled Mussolini into thinking him a Fascist, has an odd observation on this subject. He says somewhere that a philosophical anarchist, because of his detachment, is likely to make the best teacher of law. There are, of course, many varieties of philosophical anarchism, and one kind of philosophical anarchist is likely to be more opposed than anyone to what we commonly mean by anarchy. Whatever the form, the philosophical anarchist-for example, St. Francis or Kropotkin-is likely to be a stimulating addition to a staff of teachers dealing with any of the human subjects. If, on the other hand, he becomes an anarchist of a different sort and advocates in principle the bombing of all government buildings and officials, he cannot be surprised to find that his promotion is being blocked.

The most troublesome and serious form of the various problems about individual treatment suggested here is perhaps that raised by issues connected with the discharge of a teacher who does not have tenure. There seem to me to be extraordinarily serious objections to the discharge, or indeed the non- 
promotion, of a qualified teacher, even though he does not have tenure, on grounds of atheism, scepticism about family or property institutions, or concern with that remote and sometimes doubtless neurotic ideal of a world in which the occasions of conflict and the need for public force are almost unimaginably reduced. Is there any constitutional protection, for example in an educational institution supported by public funds, against discharge in any of the situations suggested, including the situation which may happen to appeal most to any particular reader?

I think I shall not try to answer that question, but leave it as a step toward what seem to me the somewhat easier questions raised by the Tennessee statute with which we started. A legislature provides that no teaching of evolution shall be permitted in a state university containing a department of biology, or it provides that biology is not to be taught in a state university. Is there any constitutional objection to such a provision?

Let us take the provision that evolution is not to be taught in a department of biology and leave it to the reader to consider the provision for a university without a department of biology. The first objection to the former provision is that today it is a command to do what is logically impossible. It is like the famous statute which provides that, when two trains approach a crossing, each shall whistle and neither shall proceed until the other has passed the crossing.

The second objection is that it is indeed an abridgement of freedom of speech, protected by any state constitution containing a provision like the first amendment of the United States Constitution and protected also under the United States Constitution by a reasonable interpretation of the privileges and immunties clause of the fourteenth amendment. It may be that this statement does not imply that the kind of freedom in question will be protected by any court. It seems likely that state courts will follow the lead of the United States Supreme Court in restricting its own power to disregard unconstitutional state legislation, although that power is rather clearly provided for by the Constitution, and in restricting-perhaps to an even greater extent-its power to disregard acts of Congress, a power which seems to have been much more limited by a contemporaneous understanding of the Constitution than our modern views recognize. Our question then is not so much whether the freedom in question will be protected by the courts as whether it is a constitutional protection which ought to be regarded by intelligent legislators with a conscientious regard for oaths to support state or federal Constitution or both. It is perhaps like those portions of the Constitution which will seldom or never be subjected to judicial review, for example the power of Congress to declare war, and thus in a rigorous sense perhaps not law at all. In some respects a constitution serves simply as a statement of political principle, and we shall be discussing our present problem primarily in relation to such a statement. We shall, however, suggest a theoretically possible way in which questions of the sort with which we are concerned could be presented for adjudication to a court. 
Provision for the teaching of non-evolutionary biology alone, in a public institution, made by a legislature or by an administrative body, appears to be a serious interference with and an abridgment of freedom of speech. The speech of teachers is immediately abridged. All the serious apparent consequences follow for students, parents, student or parent taxpayers, community generally, and taxpayers generally. These consequences result from an abridgment or decrease of freedom of speech as compared with that ideal or "natural" freedom to which, in the common understanding of its time, the first amendment, like similar state provisions, refers.

A state, in the absence of specific constitutional provisions on the subject, may doubtless fail to provide at all for public education. It does not follow that it may provide for public education on conditions which violate the Constitution. A state may prohibit foreign corporations from doing any business within its territory. But it may not permit a foreign corporation to do business there on condition that it submit to discriminatory taxation. The doctrine of unconstitutional conditions has many applications in our law, and it is enough to dispose of the simple argument based on a state's freedom to avoid undertaking any public education.

It may be not only that astrology furnishes an example of a subject which may legitimately be excluded from the curriculum, but that it also suggests problems about kinds of teaching that may not legitimately be included in a curriculum at any educational institution, private or public. Suppose that a student who has been taught astrology as a form of astronomy, or nonevolutionary biology, or some of the forms of theological biology currently taught in fundamentalist institutions, Catholic and Protestant alike, later discovers the misleading character of the teaching which he has received. What are likely to be his views about the moral responsibility of the institution in question? If he feels that he has been mistreated and has spent time and money uselessly, or even harmfully, has he a legitimate moral complaint? If so, is not our view of this complaint relevant to our views about the relationship of the case, at least if it involves a public institution, to constitutional guarantees of free speech regarded as statements of political principle?

It may indeed be suggested that a student in the case supposed would have at least an arguable cause of action against a private institution or against a public institution under statutes allowing a public agency to be subjected to an action for breach of contract. In a few states he may have a tort action against the private institution, and in a few against the public institution, for fraud. It is hard to suppose that any educational institution does not "warrant" its teachings free from fraud, and so subject itself to possible contractual liability on this account. Doubtless a defense based on freedom of speech would be urged in answer to such a claim. The defense would derive some of its strength from our common acceptance of the theory of the golden lie and its usefulness in the work of religion and government alike. It seems doubtful, however, that 
the golden lie is protected by the first amendment or by comparable provisions in state constitutions.

The golden lie has its uses, and Roman emperors, Catholic ecclesiastical and lay rulers, and Communist Party leaders alike may base defensible theories of government upon it. In a world like ours its use is likely to become more and more impracticable. Nor is it always as necessary or useful as is sometimes supposed. Simple religious sanctions for the institutions of marriage are, for many people, no longer available, and the effort to conceal this fact tends to produce confusion about the natural biological and economic reasons for these institutions. Theological biology may encourage errors about the causes of present international tension, and give false comfort about the justice and consequences of an atomic war. It has implications for all our views on public problems. It seems to be the characteristic gamble of a democratic society that its members shall have access to all defensible approximations of truth and that their access shall not be impeded by fraud any more than by force. The great democracy of Athens may or may not be thought of as having lost this gamble, but our own democracy seems to assume its acceptance. The teaching of astrology as magical physics, or non-evolutionary biology as theological science, is inconsistent with this gamble.

It may be suggested in closing that those who are concerned with the role of religion in our society might consider how persuasive a modern case can be made for the subtler forms of Greek and medieval religious teaching. Averroist, Maimonidean, Franciscan, and Thomist theologies have a symbolism whose poetical and tentative character may be thought of as suitable for understanding only by the enlightened. If, however, we expect the progressive enlightenment of ordinary people, they must be allowed some understanding of the hidden character of the teaching of the great theologians. Denial of an opportunity for such an understanding may be a defect in education comparable in character to denial of an opportunity for an understanding of biology and evolution. Fraudulent oversimplification and the concealed use of myth or magic serve neither the purposes of science nor the purposes of natural religion. Neither are they consistent with the policy of free and rational discussion which is indispensable for a democracy and implied by constitutional provisions designed to protect freedom of speech. 